\title{
PHYSICAL CHANGES OF TILAPIA FISH BURGER \\ DURING FROZEN STORAGE
}

\author{
EDUARDA M. BAINY* \\ LARISSA C. BERTAN** \\ MARCOS L. CORAZZA*** \\ MARCELO K. LENZI***
}

\begin{abstract}
The effects of frozen storage on weight loss during freezing, cooking yield, dimensional changes, and instrumental texture parameters of tilapia fish burger were evaluated during 6 months. Frozen storage for 1 month significantly increased the fish burger shear force, hardness and thickness reduction. Weight loss during freezing $(0.6$ $\pm 0.1 \%$ ) did not increase with storage time. There was no hardness $(29.9 \pm 0.7 \mathrm{~N})$ and shear force $(5.5 \pm 0.2 \mathrm{~N})$ increase during the frozen storage from 1 to 6 months. Tilapia fish burger can be stored for up to 6 months with minor physical changes.
\end{abstract}

* PhD in Food Engineering, Department of Food Engineering, Federal University of Fronteira Sul (UFFS), Laranjeiras do Sul, PR, Brazil (e-mail: ebainy@gmail.com).

** $\mathrm{PhD}$ in Food Technology, Department of Food Engineering, Federal University of Fronteira Sul (UFFS), Laranjeiras do Sul, PR, Brazil (e-mail: larissabertan@gmail.com).

** $\mathrm{PhD}$ in Chemical Engineering, Program of Food Engineering, Department of Chemical Engineering, Federal University of Paraná (UFPR), Curitiba, PR, Brazil (e-mail: corazza@ufpr.br).

${ }^{* * *}$ PhD in Chemical Engineering, Department of Chemical Engineering, Federal University of Paraná (UFPR), Curitiba, PR, Brazil (e-mail: corazza@ufpr.br). 


\section{INTRODUCTION}

Fish is a great source of nutrients and contains high quality protein, polyunsaturated fatty acids, vitamins and minerals (ORDÓÑEZ et al., 2005). Tilapia (Oreochromis niloticus) is one of the most popular fish species in the world (TOKUR et al., 2004), due to its adaptability to different environments. The development of tilapia-based products could be an alternative to aggregate value and increase fish consumption.

There are few studies on fish-based products and lack of information on the potential use of tilapia meat for fish burger production. Fish and fish-based products are commonly stored frozen, but little is known about the effects of freezing and frozen storage on the quality characteristics of fish-based products. Freezing is a food preservation method that can be used to extend the shelf life of fish products. Freezing is based on the reduction of food temperature at temperatures below the freezing point, when water changes from liquid to solid to form ice crystals (FELLOWS, 2000).

Biscalchin-Grÿschek, Oetterer and Gallo (2003) conducted physicochemical and microbiological analysis of frozen mince tilapia (Oreochromis spp.) and concluded that the mince was in good condition for consumption for 6 months at $16{ }^{\circ} \mathrm{C}$. AlBulushi et al. (2013) studied the effect of frozen storage on the physicochemical, chemical and microbiological characteristics of fish sausage. Tokur et al. (2004) evaluated the chemical and sensory changes on tilapia fish burger during frozen storage. Other studies have evaluated the quality and stability during frozen storage of fish burgers made from Catla (Catla catla) (VANITHA et al., 2013) and Arabian sea meagre (Argyrosomus heinii) (AL-BULUSHI et al., 2005). These studies established that fish burgers were acceptable for 3 months at $-20^{\circ} \mathrm{C}$, approximately 6 months at $-20^{\circ} \mathrm{C}$ and 8 months at $18^{\circ} \mathrm{C}$ (AL-BULUSHI et al., 2005; TOKUR et al., 2004; VANITHA et al., 2013), respectively.

However, to the best of our knowledge, no studies evaluating the changes in physical and instrumental textural properties of fish burger produced from tilapia (Oreochromis niloticus) meat during frozen storage have been reported in literature, which was the aim of the present study. Physical changes, such as dimensional reduction, weight loss and textural changes can occur during frozen storage and are perceived negatively by consumers. This study monitored these properties during 6 months of frozen storage at $18^{\circ} \mathrm{C}$.

\section{MATERIAL AND METHODS}

\subsection{FISH BURGER PREPARATION}

Fresh tilapia fillets (Oreochromis niloticus) were obtained from a local market in the city of Curitiba (Paraná, Brazil) and were processed immediately as described by Bainy et al. (2014). The formulation was based on Bochi et al. (2008) with modifications. $880 \mathrm{~g}$ minced tilapia and 120 $\mathrm{g}$ hydrated textured soy protein (TSP) (1:2 w/v TSP/water) were used for each batch of $1000 \mathrm{~g}$. The following ingredients were added in the mixture: $5 \%$ wheat flour, $5 \%$ sunflower oil, $10 \%$ cold water, $1.5 \%$ salt, $0.2 \%$ monosodium glutamate and spices $(0.1 \%$ onion powder, $0.1 \%$ garlic powder, $0.2 \%$ coriander and $0.1 \%$ white pepper). The approximate composition ( $\mathrm{g} / 100 \mathrm{~g}$ sample) for cooked fish burger was $68.3 \pm 0.2 \%$ (moisture), $6.6 \pm 0.2 \%$ (lipids), $16.5 \pm 0.1 \%$ (protein) and $2.7 \pm 0.1 \%$ (ash), respectively, as reported in a previous study conducted by the authors (BAINY et al., 2014). The remaining percentage of the approximate composition is due to carbohydrates used in the fish burger formulation, such as wheat flour. Five separate batches of fish burgers were made. Each batch consisted of approximately 15 burgers. The batter was maintained at low temperature (ice water bath) and was mixed manually until a homogenous mass was obtained. This mixture was weighed and formed using a conventional burger formto obtain burgers of approximately $80 \mathrm{~g}$, $100 \mathrm{~mm}$ diameter and $80 \mathrm{~mm}$ thickness. Following formation, the fish burgers were individually 
packaged in high-density polyethylene bags, placed on trays and frozen overnight at $18{ }^{\circ} \mathrm{C}$ in a freezer. Burgers were then packed in cardboard boxes and stored at $18^{\circ} \mathrm{C}$ in a household horizontal freezer (Consul CHA31, Whirlpool S.A., São Paulo, Brazil) for up to 6 months. Fresh fish burgers were analyzed immediately and were not frozen.

\subsection{COOKING PROCEDURE}

Five fish burgers were cooked at $150{ }^{\circ} \mathrm{C}$ in a forced air convection oven (Vipinho, mod. 0448, Curitiba, Brazil) to a core temperature of $76^{\circ} \mathrm{C}$. The oven was preheated for $10 \mathrm{~min}$. The internal temperature was determined at the geometric center of the fish burgers by inserting a T-type thermocouple which was connected to a temperature logger (Novus, mod. FieldLogger, Porto Alegre, Brazil), as described by Bainy et al. (2014). Fish burgers were weighed before and after cooking to determine percentage cooking yield (Equation 1):

Equation $1 \quad \%$ Cooking yield $=($ cooked weight $) /($ raw weight $) \times 100$

\subsection{PH AND WATER ACTIVITY ANALYSIS}

The $\mathrm{pH}$ was measured on a suspension resulting from blending a $10 \mathrm{~g}$ cooked sample with $100 \mathrm{~mL}$ distilled water for $2 \mathrm{~min}$ with a pH meter (Tecnopon, mod. mPA210, Piracicaba, Brazil). Water activity $\left(a_{w}\right)$ was measured at $25^{\circ} \mathrm{C}$ using an Aqualab system (mod. series 3TE, Pullman, USA) with direct readings. Determinations were performed in triplicate.

\subsection{DIMENSIONAL CHANGES}

Diameter and thickness measurements were performed in raw and cooked fish burger samples, using a 0-150 $\mathrm{mm}$ digital caliper. Two diameter measurements and four thickness measurements were taken for each sample using fixed locations (BERRY, 1992). To estimate dimensional changes, reduction in diameter (Equation 2) and thickness (Equation 3) were calculated from the following equations:

\section{Equation 2 \%Diameter reduction $=($ raw diameter - cooked diameter $) /($ raw diameter $) \times 100$ \\ Equation $3 \%$ Thickness reduction $=($ raw thickness - cooked thikness $) /($ raw thickness $) \times 100$ \\ 2.5 WEIGHT LOSS DURING FREEZING}

Five fish burgers were weighed before freezing (raw, refrigerated) and after freezing (1 to 6 months). Percent weight loss during freezing was calculated as follows:

Equation $4 \quad \%$ Weight loss $=($ raw weight- frozen weight $) /($ raw weight $) \times 100$

\subsection{TEXTURE PROFILE ANALYSIS}

Texture profile analysis (TPA) was performed on cooked samples at room temperature (approximately $2 \mathrm{~h}$ after cooking) with 22using a CT3 Texture Analyser (Brookfield, Middleboro, USA). Three cylindrical samples ( $2.5 \mathrm{~cm}$ diameter) were sampled from each fish burger and subjected to a two-cycle compression (GANHÃO; MORCUENDE \& ESTÉVEZ, 2010). Samples were compressed to $40 \%$ of the original height with a cylindrical probe (TA25/1000) $50.8 \mathrm{~mm}$ diameter using test speed of $5 \mathrm{~mm} / \mathrm{s}$. 
The texture profile parameters were determined following descriptions by Bourne (1978) and interpreted as follows. 1) Hardness $(\mathrm{N})$ is the maximum force required to compress the sample and the first compression peak; 2) Cohesiveness is the extent to which the sample can be deformed before rupture (ratio A2/A1), A1 being the total energy required for the first compression (area of the first compression) and $\mathrm{A} 2$ is the total energy required for the second compression (area of the second compression); 3) Springiness (cm) is the ability of the sample to recover its original shape when the deforming force is removed; 4) Gumminess $(\mathrm{N})$ is the energy required to disintegrate a semisolid sample to a state ready for swallowing (hardness $x$ cohesiveness) and 5 ) Chewiness (N.cm 10-2 or $\mathrm{J}$ ) is the work required to chew a sample to a steady state of swallowing (springiness $x$ gumminess).

\subsection{SHEAR TESTS}

Two cylindrical samples $(2.5 \mathrm{~cm}$ diameter) were taken for each fish burger. The samples were subjected to a shear test with a Warner-Bratzler blade attached to the same texture analyzer. The crosshead speed was $4 \mathrm{~mm} / \mathrm{s}$ (TROY; DESMOND \& BUCKLEY, 1999). The maximum force required to cut the sample (shear force) and the work required to move the blade through the samples (work of shearing) were obtained.

\subsection{STATISTICAL ANALYSIS}

The results were expressed as mean \pm standard of error. Data were analyzed with Analysis of Variance (ANOVA). When differences were considered significant $(p<0.05)$, post hoc analysis was performed by the Tukey's test to find the significance among storage months. The software used was Statistica for Windows (Statsoft Inc., Tulsa, USA).

\section{RESULTS AND DISCUSSION}

The $\mathrm{pH}$ values, weight loss during freezing, cooking yield, reduction in diameter and thickness determined in fish burger samples not subjected to freezing (Fresh) and during frozen storage for 6 months are shown in Table 1.

\section{TABLE 1 - pH VALUES, WEIGHT LOSS DURING FROZEN STORAGE, COOKING YIELD AND DIMENSIONAL CHANGES OF TILAPIA FISH BURGER DURING FROZEN STORAGE}

\begin{tabular}{|c|c|c|c|c|c|c|c|c|c|c|c|c|c|c|c|}
\hline \multirow{2}{*}{$\begin{array}{l}\text { Months } \\
\text { Fresh } \\
\end{array}$} & \multicolumn{3}{|c|}{$\mathrm{pH}$} & \multicolumn{3}{|c|}{$\begin{array}{c}\text { Weight loss } \\
(\%)\end{array}$} & \multicolumn{3}{|c|}{$\begin{array}{c}\text { Cooking yield } \\
(\%)\end{array}$} & \multicolumn{3}{|c|}{$\begin{array}{c}\text { Diameter } \\
\text { reduction (\%) }\end{array}$} & \multicolumn{3}{|c|}{$\begin{array}{l}\text { Thickness } \\
\text { reduction (\%) }\end{array}$} \\
\hline & 6.3 & \pm & $0.1^{\mathrm{a}}$ & & - & & 88.4 & \pm & $0.2^{\mathrm{c}}$ & 6.6 & \pm & $0.4^{\mathrm{a}}$ & -17.8 & \pm & $0.5^{\mathrm{c}}$ \\
\hline 1 & 6.3 & \pm & $0.1^{\mathrm{a}}$ & 0.6 & \pm & $0.1^{\mathrm{a}}$ & 85.2 & \pm & $0.5^{\mathrm{b}}$ & 6.5 & \pm & $0.6^{\mathrm{a}}$ & 14.6 & \pm & $1.1^{\mathrm{b}}$ \\
\hline 2 & 6.3 & \pm & $0.1^{\mathrm{a}}$ & 0.5 & \pm & $0.1^{\mathrm{a}}$ & 84.7 & \pm & $0.6^{\mathrm{ab}}$ & 6.7 & \pm & $0.3^{\mathrm{a}}$ & 18.7 & \pm & $1.4^{b}$ \\
\hline 3 & 6.4 & \pm & $0.1^{\mathrm{a}}$ & 1.0 & \pm & $0.2^{\mathrm{a}}$ & 82.9 & \pm & $0.6^{a}$ & 7.7 & \pm & $0.6^{\mathrm{a}}$ & 26.1 & \pm & $1.7^{\mathrm{a}}$ \\
\hline 4 & 6.4 & \pm & $0.1^{\mathrm{a}}$ & 1.2 & \pm & $0.2^{\mathrm{a}}$ & 84.0 & \pm & $0.4^{\mathrm{ab}}$ & 8.1 & \pm & $0.6^{\mathrm{a}}$ & 25.6 & \pm & $1.3^{\mathrm{a}}$ \\
\hline 5 & 6.4 & \pm & $0.1^{\mathrm{a}}$ & 1.0 & \pm & $0.2^{\mathrm{a}}$ & 84.6 & \pm & $0.4^{\mathrm{ab}}$ & 7.3 & \pm & $0.2^{\mathrm{a}}$ & 28.0 & \pm & $1.2^{\mathrm{a}}$ \\
\hline 6 & 6.4 & \pm & $0.1^{a}$ & 1.1 & \pm & $0.2^{\mathrm{a}}$ & 83.0 & \pm & $0.3^{a}$ & 7.0 & \pm & $0.6^{a}$ & 24.8 & \pm & $0.8^{a}$ \\
\hline
\end{tabular}

Results are expressed as mean \pm standard error.

Different letters in the same column represent different results by Tukey's test $(p<0.05)$. 
No significant difference was observed in $\mathrm{pH}$ (Table 1) and water activity (results not shown) of the fish burger within the 6 months of frozen storage, which were approximately 6.4 and 0.98 , respectively. Tokur et al. (2006) also no significant difference was found between the initial and final $\mathrm{pH}$ (6.8 to 6.7) of fish fingers made from carp (Cyprinus carpio) within 5 months of storage at -18 ${ }^{\circ} \mathrm{C}$. Das et al. (2008)pH, moisture and fat percentage whereas protein content and water holding capacity (\% expressible water also reported no changes in $\mathrm{pH}$ of goat meat nuggets, which remained around 6.4 up to 3 months of frozen storage $\left(-18^{\circ} \mathrm{C}\right)$. The same behavior was observed in a previous study (SAHOO and ANJANEYULU, 1996) for buffalo meat nuggets during frozen storage. Das et al. (2008) $\mathrm{pH}$, moisture and fat percentage whereas protein content and water holding capacity $(\%$ expressible water concluded that this effect is due to the microbial growth inhibition during frozen storage.

Weight loss during freezing is an important quality factor for the industry, because the sublimation of ice produces a dehydrated surface modifying food appearance, color, texture, and flavor (CAMPAÑONE; SALVADORI \& MASCHERONI, 2001). The weight loss depends on the type of freezer, freezing time, type of food to be frozen, air speed and freezer operating conditions (JOHNSTON et al., 1994). In the present study, weight losses during freezing ranged from 0.5 and $1.2 \%$. Similar results were found in a previous research (JOHNSTON et al., 1994) which obtained values ranging from $0.5 \%$ to $1 \%$ for fish frozen by forced-air and plate freezing. Weight loss during freezing can occur due to dehydration by sublimation of ice from the food surface with a non-adhering packaging (CAMPAÑONE; SALVADORI \& MASCHERONI, 2001). Table 1 shows that no significant difference was observed with storage time, consequently the polyethylene bags used to package the burgers protected the product from dehydration with time. Johnston et al. (1994) also concluded that frozen storage time is not directly related to weight loss. Weight loss during freezing was not determined for the fresh samples as they were not subjected to freezing.

Monitoring the dimensional changes and cooking characteristics is important for maintaining the quality standards of fish burgers, since consumers negatively relate the decrease of burger dimensions with excessive water addition (SÁNCHEZ-ZAPATA et al., 2010). The highest cooking yield and lowest thickness reduction were found in the fresh sample. The freezing of fish burger significantly decreased the cooking yield from 88.4 to $85.2 \%$ and increased the thickness reduction $(-17.8 \%$ to $14.6 \%)$. The negative value found for the fresh sample is due to the thickness increase with cooking. Previous studies Besbes et al. (2008) and López-Vargas et al. (2014) also found a thickness increase for cooked pork and beef burgers, respectively.

The other samples had a thickness reduction since they were initially measured at frozen state. Burger thickness increased with freezing since the volume of water increases when it freezes. Thickness reduction in months 1 and 2 were not statistically different. Additionally, a thickness reduction was observed from month 2 up to 6 months of frozen storage. This reduction may be due to several factors including water loss as an effect of frozen storage time and temperature fluctuations during frozen storage. On the other hand, diameter reduction was not affected during frozen storage.

Cooking yield decreased from 85.2 to $82.9 \%$ during the six months of frozen storage, but no tendency was observed over the frozen storage time. This result may be due to a decrease in water holding capacity (WHC) caused by protein denaturation by freezing. Some proteins such as myoglobin undergo denaturation during refrigerated storage at temperatures below $0^{\circ} \mathrm{C}$ (DAMADORAN, 1996). A lower WHC leads to a greater loss of water during cooking which decreases the cooking yield. Das et al. (2008) $\mathrm{pH}$, moisture and fat percentage whereas protein content and water holding capacity (\% expressible water also reported a decrease in WHC of goat nuggets after 1 month of frozen storage at $18^{\circ} \mathrm{C}$. Similar results for beef burgers stored at $-18^{\circ} \mathrm{C}$ for 7 months were obtained in a previous study (CHEN; SINGH \& REID, 1989).

The texture profile analysis and Warner-Bratzler parameters during six months of frozen storage are shown in Table 2 and Table 3, respectively. 
TABLE 2 - TEXTURE PROFILE PARAMETERS OF FISH BURGER DURING FROZEN STORAGE

\begin{tabular}{ccccccccccccccccc}
\hline Months & \multicolumn{3}{c}{ Hardness $(\mathbf{N})$} & \multicolumn{2}{c}{ Gumminess (N) } & \multicolumn{2}{c}{ Elasticity $(\mathbf{c m})$} & Cohesiveness & \multicolumn{2}{c}{ Chewiness } \\
\hline Fresh & 23.4 & \pm & $0.9^{\mathrm{b}}$ & 12.6 & \pm & $0.3^{\mathrm{c}}$ & 0.30 & \pm & $0.01^{\mathrm{bc}}$ & 0.42 & \pm & $0.02^{\mathrm{a}}$ & 0.04 & \pm & $0.00^{\mathrm{c}}$ \\
\hline 1 & 29.9 & \pm & $0.7^{\mathrm{a}}$ & 16.1 & \pm & $0.6^{\mathrm{bc}}$ & 0.29 & \pm & $0.01^{\mathrm{c}}$ & 0.41 & \pm & $0.02^{\mathrm{a}}$ & 0.05 & \pm & $0.00^{\mathrm{bc}}$ \\
\hline 2 & 33.0 & \pm & $2.1^{\mathrm{a}}$ & 19.3 & \pm & $1.1^{\mathrm{ab}}$ & 0.33 & \pm & $0.01^{\mathrm{ab}}$ & 0.47 & \pm & $0.02^{\mathrm{a}}$ & 0.06 & \pm & $0.01^{\mathrm{ab}}$ \\
\hline 3 & 32.7 & \pm & $1.1^{\mathrm{a}}$ & 18.6 & \pm & $0.7^{\mathrm{ab}}$ & 0.33 & \pm & $0.01^{\mathrm{ab}}$ & 0.46 & \pm & $0.02^{\mathrm{a}}$ & 0.06 & \pm & $0.00^{\mathrm{ab}}$ \\
\hline 4 & 32.6 & \pm & $0.8^{\mathrm{a}}$ & 19.8 & \pm & $0.8^{\mathrm{a}}$ & 0.34 & \pm & $0.01^{\mathrm{a}}$ & 0.48 & \pm & $0.02^{\mathrm{a}}$ & 0.07 & \pm & $0.00^{\mathrm{a}}$ \\
\hline 5 & 32.5 & \pm & $1.6^{\mathrm{a}}$ & 20.6 & \pm & $1.3^{\mathrm{a}}$ & 0.33 & \pm & $0.01^{\mathrm{a}}$ & 0.49 & \pm & $0.02^{\mathrm{a}}$ & 0.07 & \pm & $0.01^{\mathrm{a}}$ \\
\hline 6 & 35.5 & \pm & $1.4^{\mathrm{a}}$ & 21.3 & \pm & $0.8^{\mathrm{a}}$ & 0.33 & \pm & $0.01^{\mathrm{ab}}$ & 0.49 & \pm & $0.02^{\mathrm{a}}$ & 0.07 & \pm & $0.00^{\mathrm{a}}$ \\
\hline
\end{tabular}

Results are expressed as mean \pm standard error.

Different letters in the same column represent different results by Tukey's test $(p<0.05)$.

\section{TABLE 3 - WARNER-BRATZLER PARAMETERS OF FISH BURGER DURING FROZEN STORAGE}

\begin{tabular}{ccccccc}
\hline Months & \multicolumn{3}{c}{ Shear force $(\mathbf{N})$} & \multicolumn{3}{c}{ Work of shearing $(\mathrm{J})$} \\
\hline Fresh & 4.0 & \pm & $0.2^{\mathrm{b}}$ & 0.08 & \pm & $0.01^{\mathrm{c}}$ \\
\hline 1 & 5.5 & \pm & $0.2^{\mathrm{a}}$ & 0.10 & \pm & $0.00^{\mathrm{ab}}$ \\
\hline 2 & 5.6 & \pm & $0.2^{\mathrm{a}}$ & 0.09 & \pm & $0.00^{\mathrm{ac}}$ \\
\hline 3 & 5.7 & \pm & $0.2^{\mathrm{a}}$ & 0.10 & \pm & $0.00^{\mathrm{ab}}$ \\
\hline 4 & 6.2 & \pm & $0.3^{\mathrm{a}}$ & 0.11 & \pm & $0.00^{\mathrm{b}}$ \\
\hline 5 & 5.5 & \pm & $0.2^{\mathrm{a}}$ & 0.10 & \pm & $0.00^{\mathrm{ab}}$ \\
\hline 6 & 5.8 & \pm & $0.4^{\mathrm{a}}$ & 0.10 & \pm & $0.01^{\mathrm{ab}}$ \\
\hline
\end{tabular}

Results are expressed as mean \pm standard error.

Different letters in the same column represent different results by Tukey's test $(p<0.05)$.

Frozen storage for 1 month increased the fish burger hardness (Table 2) and shear force (Table 3) from $23.4 \mathrm{~N}$ to $29.9 \mathrm{~N}$, and $4.0 \mathrm{~N}$ to $5.5 \mathrm{~N}$, respectively. This increase is probably related to the weight loss $(0.6 \%)$, as well as, the decrease in cooking yield and thickness, as shown in Table 1. Weight loss during freezing and hardness were correlated $(r>0.89)$. The water loss during storage increases hardness since the water provides less resistance to compression (RODRÍGUEZ-CARPENA et al., 2011; YOUSSEF and BARBUT, 2009)sunflower (S.

The hardness increase of hamburgers during refrigerated storage may be attributed to different factors, such as the formation of protein carbonylation, the loss of protein functionality and formation of cross-links between proteins (GANHÃO; MORCUENDE \& ESTÉVEZ, 2010). Changes in fish texture are directly related to changes in myofibrillar proteins, which are present in greater proportion (65-75\% of total) in fish (ORDÓÑEZ et al., 2005). Changes in the texture of frozen fish fillets have also been associated with changes in muscle proteins, such as protein denaturation 
(BADII and HOWELL, 2002), resulting in a loss of water retention capacity and increasing hardness of the frozen fish filets (NG and BAHURMIZ, 2009).

The fish burger of this study presented hardness $(\sim 23 \mathrm{~N})$ similar to the values $(25.7 \mathrm{~N})$ found for sausage made from geelbeck croaker (Atractoscion aequidens) (RAHMAN et al., 2007). The shear force ranged from 7 to $11 \mathrm{~N}$ for goat meat nuggets, thus demonstrating the soft texture of tilapia fish burger, which had values around 4 to $6 \mathrm{~N}$. The frozen storage time (1 to 6 months) did not affect the hardness and shear force values of fish burgers.

The results of instrumental texture of the present study are consistent with the results found in a previous study with tilapia fish burger (TOKUR et al., 2004). They found no significant changes in the texture of frozen tilapia fish burger for up to eight months, assessed by sensory analysis performed with a trained panel. HassAballa et al. (2009) also found no significant difference in sensory texture of fish burger from catfish (Clarias spp) during 4 months of frozen storage. Frozen storage for five months did not affect the shear force of beef patties (LÓPEZ-LÓPEZ et al., 2010). Other studies (BADII and HOWELL, 2002; NG and BAHURMIZ, 2009) showed an increase in hardness of fish fillets with frozen storage time. To the best of our knowledge, no studies were conducted on the changes of instrumental texture of fish burger during frozen storage. The work of shearing (Table 3) had no trend pattern and ranged from $0.08 \mathrm{~J}$ to $0.11 \mathrm{~J}$ during the evaluation period; therefore, this texture parameter was not sensitive to changes in texture with storage time.

The gumminess values of fish burgers subjected to freezing for up to one month were between $12.6 \mathrm{~N}$ and $16.1 \mathrm{~N}$. Similar changes were observed for gumminess and chewiness during frozen storage from 1 to 3 months, with no difference between 2 to 6 months. Besides that, the gumminess ( 16.1 to $21.3 \mathrm{~N})$, and chewiness $(0.05$ to $0.07 \mathrm{~J})$ increased significantly when comparing the first month to the 4th to 6th months of frozen storage. It was observed that the thickness reduction (Table 1) had a significant increase from the 3rd month of storage, which may be related to this increase in gumminess and chewiness parameters. Additionally, a correlation was observed between the results of thickness reduction and chewiness $(r>0.89)$, as well as, thickness reduction and gumminess $(r>0.87)$.

The texture of minced tilapia fish balls was analyzed by sensory evaluation and a rubbery texture was observed from the 4th month of frozen storage at $20^{\circ} \mathrm{C}$ (NINAN; BINDU \& JOSEPH, 2010). The authors concluded that this toughening of texture may have been caused by the formation of covalent bonds between the carbonyl groups of oxidized lipids and muscle proteins. Even though, we observed an increase in gumminess and chewiness with storage time, the values found in this study were lower than other meat products, confirming that tilapia fish burger has a soft texture and maintains it with 6-month of storage time at $18^{\circ} \mathrm{C}$.

No difference was observed for the elasticity and cohesiveness during the storage period (Table 2). The elasticity varied from 0.29 to $0.34 \mathrm{~cm}$, similar to the value $(0.33 \mathrm{~cm})$ found for ostrich burger (FERNÁNDEZ-LÓPEZ et al., 2006). However, the present results were lower than the values found for goat nuggets $(0.72$ to $0.81 \mathrm{~cm})$ (DAS et al., 2008)pH, moisture and fat percentage whereas protein content and water holding capacity (\% expressible water and pork burger $(0.96 \mathrm{~cm})$ (GANHÃO; MORCUENDE \& ESTÉVEZ, 2010).

\section{CONCLUSION}

The freezing of fish burgers increased the thickness reduction and weight loss during freezing. Higher hardness and shear force values were observed after 1 month of frozen storage. The 6-month frozen storage period had no effect on diameter reduction. High cooking yields were obtained for up to 6 months of frozen storage. These are desirable characteristics since dimensional changes are viewed negatively by the consumer who associates the shrinkage during cooking with the effect of water addition. Additionally, hardness and shear force did not increase during 1 to 6 months of frozen storage. 


\section{RESUMO}

\section{MUDANÇAS FÍSICAS DO FISHBURGUER DE TILÁPIA DURANTE ARMAZENAGEM SOB CONGELAMENTO}

Os efeitos da armazenagem na perda de massa durante o congelamento, rendimento na cocção, mudanças dimensionais e nos parâmetros de textura instrumental de fishburger de tilápia foram avaliados durante 6 meses. O armazenamento por 1 mês aumentou significativamente a força de cisalhamento, a dureza e a redução do diâmetro do fishburger. A perda de massa durante congelamento $(0,6 \pm 0,1 \%)$ não aumentou com o tempo de armazenagem. Não houve aumento na dureza $(29,9 \pm 0,7 \mathrm{~N})$ e força de cisalhamento $(5,5 \pm 0,2 \mathrm{~N})$ durante a armazenagem congelada de 1 a 6 meses. Fishburger de tilápia pode ser armazenado por até 6 meses com pouca alteração nos parâmetros físicos avaliados.

PALAVRAS-CHAVE: TILÁPIA DO NILO; CONGELAMENTO; MUDANÇAS DIMENSIONAIS; WARNERBRATZLER; ANÁLISE DO PERFIL DE TEXTURA.

\section{ACKNOWLEDGMENTS}

The authors thank the CNPq and CAPES (Brazilian Agencies) for financial support and scholarships. 